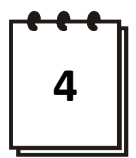

\title{
Desa Tertinggal di Indonesia
}

\author{
Ivanovich Agusta ${ }^{1}$
}

\section{Ringkasan}

Tulisan ini membuka debat desa tertinggal di Indonesia, karena hasil perhitungan ini telah digunakan oleh Pemerintah Republik Indonesia dalam Program Kompensasi Pengurangan Subsidi BBM (PKPS-BBM) tahun 2005. Namun secara teoritis muncul dilema antara menggunakan kategorisasi desa tertinggal versi terdahulu dalam rangka membanding angka desa tertinggal antar tahun, dan memperkaya kategori tersebut dengan variabel tambahan yang muncul menjadikannya sulit dibandingkan dengan data-data sebelumnya.

Ternyata jumlah desa tertinggal di Indonesia saat ini 11.258 desa, atau 10.758 desa jika NAD tidak dimasukkan. Data ini berbasis Potensi Desa 2003 terbaru. Kategorisasi pengolahan desa tertinggal memiliki bias pada desa pertanian, serta belum mencakup desa-desa hasil pemekaran sejak 2003. Jika desa tertinggal hendak digunakan sebagai indikasi kantong kemiskinan, perlu disadari bahwa dominasi rumahtangga miskin hanya terdapat pada 51 persen desa tertinggal.

Katakunci: Desa miskin, PKPS BBM, Podes 2003

\section{Pendahuluan}

Tulisan ini disusun untuk membuka debat tentang desa-desa tertinggal di Indonesia. Pada sisi praktis, hasil perhitungan saya telah digunakan oleh Pemerintah Republik Indonesia dalam Program Kompensasi Pengurangan Subsidi BBM (PKPS-BBM) pada saat ini (tahun 2005). Pada sisi teoritis, muncul dilema antara menggunakan kategorisasi desa tertinggal versi terdahulu dalam rangka membanding angka desa tertinggal antar tahun, dan memperkaya kategori tersebut dengan variabel tambahan yang muncul menjadikannya sulit dibandingkan dengan data-data sebelumnya.

Sebetulnya, ketika akhirnya daftar desa tertinggal selesai saya susun dari sumber, rencananya deretan data itu menjadi sebagai salah satu patokan pembangunan desa tahun 2005 ini. Artinya data tersebut bisa digunakan untuk membangun desa dari sisi tertutama infrastruktur, serta juga ekonomi, politik, sosial dan budaya. Melalui fakta-fakta terbaru yang menjadi basis data tersebut, harapan saya kepentingan pemerintah dan kebutuhan masyarakat desa semakin mengerucut sampai akhirnya bertemu.

\footnotetext{
${ }^{1}$ Dosen pada Departemen Komunikasi dan Pengembangan Masyarakat IPB dan sedang menempuh program doktor pada Program Studi Sosiologi Pedesaan Sekolah Pasca Sarjana IPB.
} 
Ternyata daftar inipun dipasang sebagai landasan alokasi dana kompensasi pengalihan subsidi BBM bagi desa tertinggal. Oleh karena alasan kebijakan yang tidak populer ini meningkatkan derajat ketepatan pemanfaatan subsidi bagi kaum miskin, selanjutnya berimplikasikan pengawasan dari beragam pihak, kiranya di sini penting dikemukakan kelebihan dan jebakan data desa tertinggal tersebut.

Di samping itu, tindakan saya mengeluarkan data desa tertinggal itu disebabkan akses yang hampir mustahil kepada pasokan data BPS serupa setelah tahun 1998. Bahkan setidaknya hingga awal tahun 2000-an perencanaan pembangunan nasional masih juga menggunakan karya lama BPS, yang mencuatkan 28.376 desa tertinggal. Dalam salah rapat antar departemen ${ }^{2}$ terungkap pula bahwa BPS masih belum akan mengeluarkan daftar desa tertinggal dalam waktu desa. Adapun Kementerian Negara yang menangani pengembangan kawasan dan daerah tertinggal sedang mengolah data untuk mengemukakan jumlah desa tertinggal menurut perhitungannya sendiri.

Dari sinilah saya khawatir wacana yang berkutat di seputar angka 26 ribuan desa tertinggal masih melansir informasi terdahulu, ditambahi sekedar tindakan menyortir desa tertinggal di Nanggroe Aceh Darussalam (NAD). Data ketertinggalan desa di NAD tentu tidak cocok lagi setelah bencana tsunami, namun yang lebih utama karena wilayah di sana memperoleh bantuan khusus di luar alokasi kompensasi pencabutan subsidi BBM.

\section{Pengolahan Data}

Dalam menentukan jumlah desa tertinggal, digunakan data Potensi Desa (Podes) tahun 2003, yang merupakan data sensus seluruh desa terbaru yang dimiliki. Dari data dalampola sensus ini bisa dicari lokasi yang riil, di samping temuan angka garis ketertinggalan. Bandingkan dengan penggunaan data survai -misalnya Survai Sosial Ekonomi Nasional atau Susenas-yang bisa menduga tingkat kemiskinan namun buta alamat penduduk miskin sesungguhnya.

Sesuai dengan pola penghitungan BPS pada tahun 1993 (Supriatna, 1997), maka komponen desa tertinggal terbagi atas potensi desa, perumahan dan pemukiman, keadaan penduduk, serta tambahan variabel untuk daerah pedesaan. Komponen potensi desa terdiri atas variabel tipe LKMD atau lembaga yang setara, jalan utama, pola nafkah, pengusahaan lahan pertanian. Juga variabel jarak desa ke kecamatan, fasilitas pendidikan, kesehatan, komunikasi, dan pasar.

Komponen perumahan dan pemukiman terdiri atas kepadatan penduduk, sumber air minum, wabah penyakit, bahan bakar, pembuangan sampah, jamban, penerangan umum, tempat ibadah. Selanjutnya komponen keadaan

\footnotetext{
${ }^{2}$ Dosen pada Departemen Komunikasi dan Pengembangan Masyarakat, serta mahasiswa program S3 Sosiologi Pedesaan
} 
penduduk mencakup pengusahaan ternak, kepemilikan TV dan telepon. Sayang variabel kelahiran dan kematian kasar, ukuran subyek kelembagaan lokal, dan enrollment tidak ada dalam Podes 2003 sehingga dilewatkan. Akhirnya tambahan variabel untuk wilayah pedesaan ialah rumah tangga pertanian

Tiap variabel terinci atas skor satu sampai tiga, sehingga masing-masing desa mengantongi peluang skor dari 22 sampai 66. Selanjutnya garis ketertinggalan diukur dari nilai satu standard deviasi di bawah angka rata-rata. Hal ini disajikan pada Tabel 1. 
Tabel 1. Variabel dalam Menentukan Desa Tertinggal sesuai BPS Tahun 1999

\begin{tabular}{|c|c|c|c|}
\hline No & Variabel & Klasifikasi & Skor \\
\hline I & \multicolumn{3}{|l|}{ POTENSI DESA } \\
\hline \multirow{3}{*}{1} & \multirow{3}{*}{$\begin{array}{l}\text { Tipe LKMD (atau yang } \\
\text { setara) }\end{array}$} & tipe 3 & 3 \\
\hline & & tipe 1 atau 2 & 2 \\
\hline & & tipe 0 & 1 \\
\hline \multirow{3}{*}{2} & \multirow{3}{*}{ Jalan utama } & aspal & 3 \\
\hline & & diperkeras & 2 \\
\hline & & tanah & 1 \\
\hline \multirow{3}{*}{3} & \multirow{3}{*}{$\begin{array}{l}\text { Sebagian besar penduduk } \\
\text { bergantung pada potensi }\end{array}$} & jasa, perdagangan, dll & 3 \\
\hline & & industri/kerajinan & 2 \\
\hline & & pertanian & 1 \\
\hline \multirow{3}{*}{4} & \multirow{3}{*}{$\begin{array}{l}\text { Rata-rata tanah pertanian } \\
\text { yang diusahakan per } \\
\text { rumahtangga tani untuk } \\
\text { pertanian }\end{array}$} & $>1 \mathrm{Ha}$ & 3 \\
\hline & & $0,5-1 \mathrm{Ha}$ & 2 \\
\hline & & $<0,5 \mathrm{Ha}$ & 1 \\
\hline \multirow{3}{*}{5} & \multirow{3}{*}{$\begin{array}{l}\text { Jarak dari desa/kelurahan } \\
\text { ke ibukota kecamatan }\end{array}$} & $0-5 \mathrm{~km}$ & 3 \\
\hline & & $6-9 \mathrm{~km}$ & 2 \\
\hline & & $>10 \mathrm{~km}$ & 1 \\
\hline \multirow{3}{*}{6} & \multirow{3}{*}{ Fasilitas pendidikan } & s/d SLTA ke atas & 3 \\
\hline & & s/d SLTP ke atas & 2 \\
\hline & & $\mathrm{s} / \mathrm{d} \mathrm{SD}$ & 1 \\
\hline \multirow{3}{*}{7} & \multirow{3}{*}{ Fasilitas kesehatan } & Poliklinik ke atas & 3 \\
\hline & & Puskesmas & 2 \\
\hline & & Puskesmas pembantu & 1 \\
\hline \multirow{3}{*}{8} & \multirow{3}{*}{ Tenaga kesehatan } & Dokter & 3 \\
\hline & & Paramedis & 2 \\
\hline & & Dukun bayi & 1 \\
\hline \multirow{3}{*}{9} & \multirow{3}{*}{ Sarana komunikasi } & Telepon terpasang/umum & 3 \\
\hline & & Kantor pos & 2 \\
\hline & & Tidak ada sarana & 1 \\
\hline \multirow{3}{*}{10} & \multirow{3}{*}{ Pasar } & $\begin{array}{c}\text { Bangunan pasar } \\
\text { permanen/setengan permanen }\end{array}$ & 3 \\
\hline & & Kios/pertokoan & 2 \\
\hline & & Tanpa bangunan & 1 \\
\hline
\end{tabular}




\begin{tabular}{|c|c|c|c|}
\hline No & Variabel & Klasifikasi & Skor \\
\hline I & \multicolumn{3}{|l|}{ POTENSI DESA } \\
\hline \multirow{3}{*}{1} & \multirow{3}{*}{$\begin{array}{l}\text { Tipe LKMD (atau yang } \\
\text { setara) }\end{array}$} & tipe 3 & 3 \\
\hline & & tipe 1 atau 2 & 2 \\
\hline & & tipe 0 & 1 \\
\hline \multirow{3}{*}{2} & \multirow{3}{*}{ Jalan utama } & aspal & 3 \\
\hline & & diperkeras & 2 \\
\hline & & tanah & 1 \\
\hline \multirow{3}{*}{3} & \multirow{3}{*}{$\begin{array}{l}\text { Sebagian besar penduduk } \\
\text { bergantung pada potensi }\end{array}$} & jasa, perdagangan, dll & 3 \\
\hline & & industri/kerajinan & 2 \\
\hline & & pertanian & 1 \\
\hline \multirow{3}{*}{4} & \multirow{3}{*}{$\begin{array}{l}\text { Rata-rata tanah pertanian } \\
\text { yang diusahakan per } \\
\text { rumahtangga tani untuk } \\
\text { pertanian }\end{array}$} & $>1 \mathrm{Ha}$ & 3 \\
\hline & & $0,5-1 \mathrm{Ha}$ & 2 \\
\hline & & $<0,5 \mathrm{Ha}$ & 1 \\
\hline \multirow{3}{*}{5} & \multirow{3}{*}{$\begin{array}{l}\text { Jarak dari desa/kelurahan } \\
\text { ke ibukota kecamatan }\end{array}$} & $0-5 \mathrm{~km}$ & 3 \\
\hline & & $6-9 \mathrm{~km}$ & 2 \\
\hline & & $>10 \mathrm{~km}$ & 1 \\
\hline \multirow{3}{*}{6} & \multirow{3}{*}{ Fasilitas pendidikan } & s/d SLTA ke atas & 3 \\
\hline & & s/d SLTP ke atas & 2 \\
\hline & & $\mathrm{s} / \mathrm{d} \mathrm{SD}$ & 1 \\
\hline \multirow{3}{*}{7} & \multirow{3}{*}{ Fasilitas kesehatan } & Poliklinik ke atas & 3 \\
\hline & & Puskesmas & 2 \\
\hline & & Puskesmas pembantu & 1 \\
\hline \multirow{3}{*}{8} & \multirow{3}{*}{ Tenaga kesehatan } & Dokter & 3 \\
\hline & & Paramedis & 2 \\
\hline & & Dukun bayi & 1 \\
\hline \multirow{3}{*}{9} & \multirow{3}{*}{ Sarana komunikasi } & Telepon terpasang/umum & 3 \\
\hline & & Kantor pos & 2 \\
\hline & & Tidak ada sarana & 1 \\
\hline \multirow{3}{*}{10} & \multirow{3}{*}{ Pasar } & $\begin{array}{c}\text { Bangunan pasar } \\
\text { permanen/setengan permanen }\end{array}$ & 3 \\
\hline & & Kios/pertokoan & 2 \\
\hline & & Tanpa bangunan & 1 \\
\hline
\end{tabular}




\begin{tabular}{|c|c|c|c|}
\hline II & \multicolumn{3}{|c|}{ PERUMAHAN DAN LINGKUNGAN } \\
\hline \multirow{3}{*}{11} & \multirow{3}{*}{ Kepadatan penduduk } & $0-200$ jiwa/km2 & 3 \\
\hline & & 201-299 jiwa/km2 & 2 \\
\hline & & $>300$ jiwa/km & 1 \\
\hline \multirow{3}{*}{12} & \multirow{3}{*}{ Sumber air minum } & PAM, pompa listrik & 3 \\
\hline & & Sumur pompa/mata air & 2 \\
\hline & & Air hujan & 1 \\
\hline \multirow{3}{*}{13} & \multirow{3}{*}{$\begin{array}{l}\text { Wabah penyakit selama } \\
\text { setahun }\end{array}$} & Tidak ada wabah & 3 \\
\hline & & $\begin{array}{c}\text { Selain muntaber/demam berdarah } \\
\text { paling sedikit sekali }\end{array}$ & 2 \\
\hline & & $\begin{array}{c}\text { Demam berdarah/muntaber paling } \\
\text { sedikit sekali }\end{array}$ & 1 \\
\hline \multirow{3}{*}{14} & \multirow{3}{*}{ Bahan bakar } & Listrik/gas & 3 \\
\hline & & Minyak tanah & 2 \\
\hline & & Kayu bakar & 1 \\
\hline \multirow{3}{*}{15} & \multirow{3}{*}{ Pembuangan sampah } & Tempat sampah dan diangkut & 3 \\
\hline & & Ke dalam lubang & 2 \\
\hline & & Ke sungai dll & 1 \\
\hline \multirow{3}{*}{16} & \multirow{3}{*}{ Jamban } & Sendiri & 3 \\
\hline & & Bersama-sama & 2 \\
\hline & & Bukan jamban & 1 \\
\hline \multirow{3}{*}{17} & \multirow{3}{*}{ Penerangan listrik } & Listrik PLN & 3 \\
\hline & & Listrik non-PLN & 2 \\
\hline & & Lainnya/tidak ada & 1 \\
\hline \multirow{3}{*}{18} & \multirow{3}{*}{$\begin{array}{l}\text { Rasio banyaknya tempat } \\
\text { ibadah per } 1000 \text { penduduk }\end{array}$} & $\geq 5 / 1000$ & 3 \\
\hline & & $(2-4) / 1000$ & 2 \\
\hline & & $\leq 1 / 1000$ & 1 \\
\hline III & \multicolumn{3}{|l|}{ KEADAAN PENDUDUK } \\
\hline \multirow{3}{*}{19} & \multirow{3}{*}{$\begin{array}{l}\text { Rata-rata banyaknya } \\
\text { ternak per rumahtangga } \\
\text { ternak }\end{array}$} & $\geq 5$ ekor & 3 \\
\hline & & $2-4$ ekor & 2 \\
\hline & & $\leq 1$ ekor & 1 \\
\hline \multirow{3}{*}{20} & \multirow{3}{*}{$\begin{array}{l}\text { Persentase rumah tangga } \\
\text { yang memiliki TV }\end{array}$} & $>29$ & 3 \\
\hline & & $5-29$ & 2 \\
\hline & & $<5$ & 1 \\
\hline \multirow{3}{*}{21} & \multirow{3}{*}{$\begin{array}{l}\text { Persentase rumah tangga } \\
\text { yang memiliki telepon }\end{array}$} & $>9 \%$ & 3 \\
\hline & & $1-9 \%$ & 2 \\
\hline & & $<5 \%$ & 1 \\
\hline
\end{tabular}




\begin{tabular}{|l|l|c|c|}
\hline IV & TAMBAHAN VARIABEL UNTUK DAERAH PERDESAAN \\
\hline \multirow{3}{*}{22} & \multirow{3}{*}{ Rumah tangga pertanian } & $>15 \%$ & 3 \\
\cline { 3 - 4 } & & $16-29 \%$ & 2 \\
\cline { 3 - 4 } & & $\geq 30 \%$ & 1 \\
\hline
\end{tabular}

Pada saat ini nilai rata-rata skor desa tertinggal di Indonesia (tingkat nasional) ialah 38,05. Adapun nilai satu standard deviasi ditemukan sebesar 5,79. Dengan demikian dapat ditemukan garis ketertinggalan pada angka 32,26. Desa tertinggal didefinisikan sebagai desa-desa yang memiliki nilai skor sampai maksimal 32.

Kenyataannya, menurut Podes 2003 jumlah desa tertinggal berada pada skor 2432. Selang angka demikian mengindikasikan, bahwa kondisi pedesaan secara umum masih memprihatinkan, ditandai dengan masih massifnya skor 1 atau skor rata-rata di bawah 44. Di samping itu, jelaslah bahwa ketertinggalan desa merupakan ukuran relatif kondisi urbanisasi (derajat pengkotaan wilayah), akan selalu ada, dan dengan pola penghitungan statistika di atas akan berada pada kisaran 16 persen.

Perhitungan saya sendiri menghasilkan jumlah desa tertinggal di Indonesia kini sebesar 11.258 desa -sebagaimana diiklankan di TV selama masa kampane PKPS BBM. Jika dikurangi desa-desa di NAD, otomatis angka menurun menjadi 10.754 desa (lihat Tabel 2). Ketika dikonfirmasi ke Direktorat Analisa Data BPS, ${ }^{3}$ ternyata jumlah desa per kabupaten tersebut relatif sama dengan perhitungan yang sedang dikerjakan BPS. Perbedaannya ialah, Provinsi Jawa Timur dalam perhitungan BPS memiliki desa tertinggal lebih banyak. Sayang BPS masih belum bersedia membagi model penghitungannya agar bisa dikontrol. Hanya dikatakan, bahwa BPS menggunakan sekaligus data Podes 2003 dan Susenas 2002. Sampai di sini kemudian tumbuh pertanyaan, bagaimana menggabungkan data sensus sekitar 68 ribu desa (Podes 2003) dengan data survai sekitar 65 ribu rumahtangga (Susenas 2002). Lagipula dalam rapat bersama staf kementerian yang menangani kawasan tertinggal, sempat terlontar pernyataan bahwa BPS sendiri hanya mempercayai keterandalan data Susenas sampai tingkat kabupaten. Saya khawatir penggunaan data Susenas (sekalipun untuk menakar jumlah penduduk miskin atau pendapatan wilayah) akan menimbulkan klaster-klaster perhitungan sekelompok desa, yang mengurangi keragaman dan --lebih-lebihterlalu meringkas realitas di tingkat desa.

\footnotetext{
${ }^{3}$ Oleh staf Departemen Pekerjaan Umum, TA, pada tanggal 10 Maret 2005
} 
Tabel 2. Jumlah Desa Tertinggal menurut Provinsi, 2004

\begin{tabular}{|c|c|c|}
\hline PROVINSI & KAB/KOTA & $\begin{array}{l}\text { JML } \\
\text { DT }\end{array}$ \\
\hline \multirow{4}{*}{ B A L I } & BANGLI & 2 \\
\hline & $\begin{array}{l}\text { KARANG } \\
\text { ASEM }\end{array}$ & 4 \\
\hline & KLUNGKUNG & 4 \\
\hline & Total & 10 \\
\hline \multirow{5}{*}{ BANTEN } & LEBAK & 97 \\
\hline & PANDEGLANG & 89 \\
\hline & SERANG & 31 \\
\hline & TANGERANG & 7 \\
\hline & Total & 224 \\
\hline \multirow{9}{*}{ BENGKULU } & $\begin{array}{l}\text { BENGKULU } \\
\text { SELATAN }\end{array}$ & 17 \\
\hline & $\begin{array}{l}\text { BENGKULU } \\
\text { UTARA }\end{array}$ & 40 \\
\hline & KAUR & 18 \\
\hline & KEPAHIANG & 15 \\
\hline & LEBONG & 9 \\
\hline & MUKOMUKO & 13 \\
\hline & $\begin{array}{l}\text { REJANG } \\
\text { LEBONG }\end{array}$ & 18 \\
\hline & SELUMA & 23 \\
\hline & Total & 153 \\
\hline \multirow{3}{*}{$\begin{array}{l}\text { D I } \\
\text { YOGYAKARTA }\end{array}$} & $\begin{array}{l}\text { GUNUNG } \\
\text { KIDUL }\end{array}$ & 5 \\
\hline & $\begin{array}{l}\text { KULON } \\
\text { PROGO }\end{array}$ & 1 \\
\hline & Total & 6 \\
\hline \multirow{5}{*}{ GORONTALO } & BOALEMO & 8 \\
\hline & $\begin{array}{l}\text { BONE } \\
\text { BOLANGO }\end{array}$ & 5 \\
\hline & GORONTALO & 34 \\
\hline & POHUWATO & 7 \\
\hline & Total & 54 \\
\hline
\end{tabular}

\begin{tabular}{|c|c|c|}
\hline PROVINSI & КАВ/КОТА & $\begin{array}{l}\text { JML } \\
\text { DT }\end{array}$ \\
\hline \multirow{9}{*}{$\begin{array}{l}\text { IRIAN JAYA } \\
\text { BARAT }\end{array}$} & FAKFAK & 47 \\
\hline & KAIMANA & 58 \\
\hline & MANOKWARI & 243 \\
\hline & RAJA AMPAT & 62 \\
\hline & SORONG & 54 \\
\hline & $\begin{array}{l}\text { SORONG } \\
\text { SELATAN }\end{array}$ & 107 \\
\hline & $\begin{array}{l}\text { TELUK } \\
\text { BINTUNI } \\
\end{array}$ & 77 \\
\hline & $\begin{array}{l}\text { TELUK } \\
\text { WONDAMA }\end{array}$ & 54 \\
\hline & Total & 702 \\
\hline \multirow{10}{*}{ JAMBI } & BATANG HARI & 7 \\
\hline & BUNGO & 15 \\
\hline & KERINCI & 33 \\
\hline & MERANGIN & 36 \\
\hline & MUARO JAMBI & 4 \\
\hline & SAROLANGUN & 32 \\
\hline & $\begin{array}{l}\text { TANJUNG } \\
\text { JABUNG } \\
\text { BARAT } \\
\end{array}$ & 3 \\
\hline & $\begin{array}{l}\text { TANJUNG } \\
\text { JABUNG } \\
\text { TIMUR } \\
\end{array}$ & 8 \\
\hline & TEBO & 23 \\
\hline & Total & 161 \\
\hline
\end{tabular}




\begin{tabular}{|c|c|c|}
\hline PROVINSI & КАB/КОТА & $\begin{array}{c}\text { JML } \\
\text { DT }\end{array}$ \\
\hline \multirow{17}{*}{ JAWA BARAT } & BANDUNG & 7 \\
\hline & BEKASI & 9 \\
\hline & BOGOR & 18 \\
\hline & CIAMIS & 8 \\
\hline & CIANJUR & 21 \\
\hline & CIREBON & 1 \\
\hline & GARUT & 12 \\
\hline & INDRAMAYU & 3 \\
\hline & KARAWANG & 3 \\
\hline & KUNINGAN & 10 \\
\hline & MAJALENGKA & 2 \\
\hline & PURWAKARTA & 4 \\
\hline & SUBANG & 1 \\
\hline & SUKABUMI & 17 \\
\hline & SUMEDANG & 2 \\
\hline & TASIKMALAYA & 21 \\
\hline & Total & 139 \\
\hline
\end{tabular}

\begin{tabular}{|c|c|c|}
\hline PROVINSI & KAB/КОТА & $\begin{array}{c}\text { JML } \\
\text { DT }\end{array}$ \\
\hline \multirow{25}{*}{$\begin{array}{l}\text { JAWA } \\
\text { TENGAH }\end{array}$} & $\begin{array}{l}\text { BANJARNEGAR } \\
\text { A }\end{array}$ & 34 \\
\hline & BANYUMAS & 5 \\
\hline & BATANG & 5 \\
\hline & BLORA & 7 \\
\hline & BOYOLALI & 2 \\
\hline & BREBES & 11 \\
\hline & CILACAP & 9 \\
\hline & DEMAK & 1 \\
\hline & GROBOGAN & 6 \\
\hline & JEPARA & 1 \\
\hline & KEBUMEN & 32 \\
\hline & KLATEN & 5 \\
\hline & MAGELANG & 3 \\
\hline & PATI & 2 \\
\hline & PEKALONGAN & 9 \\
\hline & PEMALANG & 3 \\
\hline & PURBALINGGA & 1 \\
\hline & PURWOREJO & 20 \\
\hline & REMBANG & 2 \\
\hline & SEMARANG & 1 \\
\hline & TEGAL & 1 \\
\hline & TEMANGGUNG & 4 \\
\hline & WONOGIRI & 5 \\
\hline & WONOSOBO & 18 \\
\hline & Total & 187 \\
\hline
\end{tabular}




\begin{tabular}{|c|c|c|}
\hline PROVINSI & КАВ/КОТА & $\begin{array}{c}\text { JML } \\
\text { DT } \\
\end{array}$ \\
\hline \multirow{27}{*}{ JAWA TIMUR } & BANGKALAN & 41 \\
\hline & BANYUWANGI & 1 \\
\hline & BLITAR & 3 \\
\hline & BOJONEGORO & 23 \\
\hline & BONDOWOSO & 11 \\
\hline & JEMBER & 14 \\
\hline & JOMBANG & 5 \\
\hline & KEDIRI & 3 \\
\hline & LAMONGAN & 5 \\
\hline & LUMAJANG & 9 \\
\hline & MADIUN & 2 \\
\hline & MALANG & 5 \\
\hline & MOJOKERTO & 1 \\
\hline & NGANJUK & 4 \\
\hline & NGAWI & 4 \\
\hline & PACITAN & 2 \\
\hline & PAMEKASAN & 30 \\
\hline & PASURUAN & 10 \\
\hline & PONOROGO & 2 \\
\hline & PROBOLINGGO & 46 \\
\hline & SAMPANG & 69 \\
\hline & SITUBONDO & 12 \\
\hline & SUMENEP & 68 \\
\hline & TRENGGALEK & 10 \\
\hline & TUBAN & 24 \\
\hline & $\begin{array}{l}\text { TULUNGAGUN } \\
\text { G }\end{array}$ & 4 \\
\hline & Total & 408 \\
\hline
\end{tabular}

\begin{tabular}{|c|c|c|}
\hline PROVINSI & KAB/KOTA & $\begin{array}{c}\text { JML } \\
\text { DT }\end{array}$ \\
\hline \multirow{12}{*}{$\begin{array}{l}\text { KALIMANTAN } \\
\text { BARAT }\end{array}$} & BENGKAYANG & 28 \\
\hline & KAPUAS HULU & 62 \\
\hline & KETAPANG & 43 \\
\hline & LANDAK & 78 \\
\hline & MELAWI & 45 \\
\hline & PONTIANAK & 10 \\
\hline & SAMBAS & 17 \\
\hline & SANGGAU & 68 \\
\hline & SEKADAU & 40 \\
\hline & SINGKAWANG & 1 \\
\hline & SINTANG & 83 \\
\hline & Total & 475 \\
\hline \multirow{11}{*}{$\begin{array}{l}\text { KALIMANTAN } \\
\text { SELATAN }\end{array}$} & BALANGAN & 11 \\
\hline & BANJAR & 31 \\
\hline & BARITO KUALA & 21 \\
\hline & $\begin{array}{l}\text { HULU SUNGAI } \\
\text { SELATAN }\end{array}$ & 10 \\
\hline & $\begin{array}{l}\text { HULU SUNGAI } \\
\text { TENGAH }\end{array}$ & 6 \\
\hline & $\begin{array}{l}\text { HULU SUNGAI } \\
\text { UTARA }\end{array}$ & 21 \\
\hline & KOTA BARU & 26 \\
\hline & TABALONG & 3 \\
\hline & TANAH BUMBU & 13 \\
\hline & TAPIN & 11 \\
\hline & Total & 153 \\
\hline
\end{tabular}




\begin{tabular}{|c|c|c|}
\hline PROVINSI & KAB/KOTA & $\begin{array}{l}\text { JML } \\
\text { DT }\end{array}$ \\
\hline \multirow{15}{*}{$\begin{array}{l}\text { KALIMANTAN } \\
\text { TENGAH }\end{array}$} & $\begin{array}{l}\text { BARITO } \\
\text { SELATAN }\end{array}$ & 34 \\
\hline & BARITO TIMUR & 9 \\
\hline & BARITO UTARA & 36 \\
\hline & GUNUNG MAS & 67 \\
\hline & KAPUAS & 72 \\
\hline & KATINGAN & 88 \\
\hline & $\begin{array}{l}\text { KOTAWARINGI } \\
\text { N BARAT }\end{array}$ & 17 \\
\hline & $\begin{array}{l}\text { KOTAWARINGI } \\
\text { N TIMUR }\end{array}$ & 75 \\
\hline & LAMANDAU & 59 \\
\hline & MURUNG RAYA & 97 \\
\hline & $\begin{array}{l}\text { PALANGKA } \\
\text { RAYA }\end{array}$ & 4 \\
\hline & PULANG PISAU & 12 \\
\hline & SERUYAN & 70 \\
\hline & SUKAMARA & 8 \\
\hline & Total & 648 \\
\hline \multirow{9}{*}{$\begin{array}{l}\text { KALIMANTAN } \\
\text { TIMUR }\end{array}$} & BERAU & 52 \\
\hline & BULONGAN & 204 \\
\hline & KUTAI & 47 \\
\hline & KUTAI BARAT & 94 \\
\hline & KUTAI TIMUR & 36 \\
\hline & MALINAU & 86 \\
\hline & PASIR & 34 \\
\hline & $\begin{array}{l}\text { PENAJAM } \\
\text { PASER UTARA }\end{array}$ & 4 \\
\hline & Total & 557 \\
\hline
\end{tabular}

\begin{tabular}{|c|c|c|}
\hline PROVINSI & КАВ/КОТА & $\begin{array}{l}\text { JML } \\
\text { DT }\end{array}$ \\
\hline \multirow{6}{*}{$\begin{array}{l}\text { KEPULAUAN } \\
\text { BANGKA } \\
\text { BELITUNG }\end{array}$} & BANGKA & 8 \\
\hline & $\begin{array}{l}\text { BANGKA } \\
\text { BARAT }\end{array}$ & 9 \\
\hline & $\begin{array}{l}\text { BANGKA } \\
\text { SELATAN }\end{array}$ & 5 \\
\hline & BELITUNG & 5 \\
\hline & $\begin{array}{l}\text { BELITUNG } \\
\text { TIMUR }\end{array}$ & 2 \\
\hline & Total & 29 \\
\hline \multirow{6}{*}{$\begin{array}{l}\text { KEPULAUAN } \\
\text { RIAU }\end{array}$} & $\begin{array}{l}\text { KEPULAUAN } \\
\text { RIAU }\end{array}$ & 5 \\
\hline & $\begin{array}{l}\text { KOTA B A T A } \\
M\end{array}$ & 1 \\
\hline & LINGGA & 15 \\
\hline & NATUNA & 12 \\
\hline & $\begin{array}{l}\text { TANJUNG } \\
\text { PINANG }\end{array}$ & 1 \\
\hline & Total & 34 \\
\hline \multirow{9}{*}{ LAMPUNG } & $\begin{array}{l}\text { LAMPUNG } \\
\text { BARAT } \\
\end{array}$ & 30 \\
\hline & $\begin{array}{l}\text { LAMPUNG } \\
\text { SELATAN }\end{array}$ & 36 \\
\hline & $\begin{array}{l}\text { LAMPUNG } \\
\text { TENGAH }\end{array}$ & 5 \\
\hline & $\begin{array}{l}\text { LAMPUNG } \\
\text { TIMUR }\end{array}$ & 9 \\
\hline & $\begin{array}{l}\text { LAMPUNG } \\
\text { UTARA }\end{array}$ & 11 \\
\hline & TANGGAMUS & 46 \\
\hline & $\begin{array}{l}\text { TULANGBAWA } \\
\text { NG }\end{array}$ & 22 \\
\hline & WAY KANAN & 13 \\
\hline & Total & 172 \\
\hline
\end{tabular}




\begin{tabular}{|c|c|c|}
\hline PROVINSI & KAB/KOTA & $\begin{array}{l}\text { JML } \\
\text { DT }\end{array}$ \\
\hline \multirow{8}{*}{ M A L U K U } & BURU & 27 \\
\hline & $\begin{array}{l}\text { KEPULAUAN } \\
\text { ARU }\end{array}$ & 106 \\
\hline & $\begin{array}{l}\text { MALUKU } \\
\text { TENGAH }\end{array}$ & 44 \\
\hline & $\begin{array}{l}\text { MALUKU } \\
\text { TENGGARA }\end{array}$ & 53 \\
\hline & $\begin{array}{l}\text { MALUKU } \\
\text { TENGGARA } \\
\text { BARAT }\end{array}$ & 159 \\
\hline & $\begin{array}{l}\text { SERAM BAGIAN } \\
\text { BARAT }\end{array}$ & 58 \\
\hline & $\begin{array}{l}\text { SERAM BAGIAN } \\
\text { TIMUR }\end{array}$ & 47 \\
\hline & Total & 494 \\
\hline \multirow{9}{*}{$\begin{array}{l}\text { MALUKU } \\
\text { UTARA }\end{array}$} & $\begin{array}{l}\text { HALMAHERA } \\
\text { BARAT }\end{array}$ & 56 \\
\hline & $\begin{array}{l}\text { HALMAHERA } \\
\text { SELATAN }\end{array}$ & 150 \\
\hline & $\begin{array}{l}\text { HALMAHERA } \\
\text { TENGAH }\end{array}$ & 18 \\
\hline & $\begin{array}{l}\text { HALMAHERA } \\
\text { TIMUR }\end{array}$ & 21 \\
\hline & $\begin{array}{l}\text { HALMAHERA } \\
\text { UTARA }\end{array}$ & 107 \\
\hline & $\begin{array}{l}\text { KEPULAUAN } \\
\text { SULA }\end{array}$ & 41 \\
\hline & $\begin{array}{l}\text { KOTA } \\
\text { TERNATE }\end{array}$ & 7 \\
\hline & $\begin{array}{l}\text { KOTA TIDORE } \\
\text { KEPULAUAN } \\
\end{array}$ & 4 \\
\hline & Total & 404 \\
\hline \multirow{8}{*}{$\begin{array}{l}\text { NUSA } \\
\text { TENGGARA } \\
\text { BARAT }\end{array}$} & BIMA & 25 \\
\hline & DOMPU & 1 \\
\hline & КОТА ВIMA & 1 \\
\hline & $\begin{array}{l}\text { LOMBOK } \\
\text { BARAT }\end{array}$ & 13 \\
\hline & $\begin{array}{l}\text { LOMBOK } \\
\text { TENGAH }\end{array}$ & 12 \\
\hline & SUMBAWA & 18 \\
\hline & $\begin{array}{l}\text { SUMBAWA } \\
\text { BARAT }\end{array}$ & 2 \\
\hline & Total & 72 \\
\hline
\end{tabular}

\begin{tabular}{|l|l|r|}
\hline \multirow{4}{*}{ PROVINSI } & \multicolumn{1}{|c|}{ KAB/KOTA } & \multicolumn{1}{c|}{ JML } \\
\hline \multirow{5}{*}{ DT } \\
\cline { 2 - 3 } & ALOR & 63 \\
\cline { 2 - 3 } & BELU & 88 \\
\cline { 2 - 3 } NESA & ENDE & 61 \\
\cline { 2 - 3 } TIMUG & FLORES TIMUR & 60 \\
\cline { 2 - 3 } & KUPANG & 40 \\
\cline { 2 - 3 } & LEMBATA & 45 \\
\cline { 2 - 3 } & MANGGARAI & 258 \\
\cline { 2 - 3 } & NGADA & 36 \\
\cline { 2 - 3 } & ROTE NDA & 16 \\
\cline { 2 - 3 } & SIKKA & 59 \\
\cline { 2 - 3 } & SUMBA BARAT & 91 \\
\hline & SUMBA TIMUR & 33 \\
\cline { 2 - 3 } & $\begin{array}{l}\text { TIMOR } \\
\text { TENGAH } \\
\text { SELATAN }\end{array}$ & \\
\cline { 2 - 3 } & $\begin{array}{l}\text { TIMOR } \\
\text { TENGAH } \\
\text { UTARA }\end{array}$ & 110 \\
\hline & Total & 48 \\
\hline
\end{tabular}




\begin{tabular}{|c|c|c|c|c|c|}
\hline PROVINSI & KAB/KOTA & $\begin{array}{l}\text { JML } \\
\text { DT }\end{array}$ & PROVINSI & KAB/KOTA & $\begin{array}{l}\text { JML } \\
\text { DT }\end{array}$ \\
\hline \multirow{22}{*}{ PAPUA } & BIAK NUMFOR & 101 & \multirow{11}{*}{ RIAU } & BENGKALIS & 13 \\
\hline & MERAUKE & 79 & & $\begin{array}{l}\text { INDRAGIRI } \\
\text { HILIR }\end{array}$ & 47 \\
\hline & ASMAT & 133 & & $\begin{array}{l}\text { INDRAGIRI } \\
\text { HULU }\end{array}$ & 27 \\
\hline & BOVEN DIGOEL & 74 & & KAMPAR & 19 \\
\hline & JAYAPURA & 36 & & KUANTAN & \\
\hline & JAYAWIJAYA & 276 & & SINGINGI & 12 \\
\hline & KEEROM & & & PELALAWAN & 18 \\
\hline & KOTA & & & ROKAN HILIR & 13 \\
\hline & JAYAPURA & 4 & & ROKAN HULU & 8 \\
\hline & MAPPI & 126 & & S I A K & 6 \\
\hline & MIMIKA & 62 & & Total & 163 \\
\hline & NABIRE & 107 & \multirow{6}{*}{$\begin{array}{l}\text { SULAWESI } \\
\text { BARAT }\end{array}$} & MAJENE & 3 \\
\hline & PANIAI & 117 & & MAMASA & 52 \\
\hline & $\begin{array}{l}\text { PEGUNUNGAN } \\
\text { BINTANG }\end{array}$ & 83 & & MAMUJU & 18 \\
\hline & PUNCAK JAYA & 136 & & $\begin{array}{l}\text { MAMUJU } \\
\text { UTARA }\end{array}$ & 7 \\
\hline & SARMI & 80 & & POLMAS & 43 \\
\hline & SUPIORI & 29 & & Total & 122 \\
\hline & TOLIKARA & 131 & & & 120 \\
\hline & WAROPEN & 37 & & & \\
\hline & YAHUKIMO & 78 & & & \\
\hline & YAPEN & 75 & & & \\
\hline & Total & 1777 & & & \\
\hline
\end{tabular}




\begin{tabular}{|c|c|c|}
\hline PROVINSI & KAB/KOTA & $\begin{array}{l}\text { JML } \\
\text { DT }\end{array}$ \\
\hline \multirow{21}{*}{$\begin{array}{l}\text { SULAWESI } \\
\text { SELATAN }\end{array}$} & BANTAENG & 13 \\
\hline & BARRU & 7 \\
\hline & BONE & 41 \\
\hline & BULUKUMBA & 14 \\
\hline & ENREKANG & 20 \\
\hline & GOWA & 8 \\
\hline & JENEPONTO & 26 \\
\hline & LUWU & 37 \\
\hline & LUWU TIMUR & 13 \\
\hline & LUWU UTARA & 39 \\
\hline & MAROS & 10 \\
\hline & $\begin{array}{l}\text { PANGKAJENE } \\
\text { KEPULAUAN }\end{array}$ & 20 \\
\hline & PINRANG & 11 \\
\hline & SELAYAR & 20 \\
\hline & $\begin{array}{l}\text { SIDENRENG } \\
\text { RAPPANG }\end{array}$ & 2 \\
\hline & SINJAI & 22 \\
\hline & TAKALAR & 3 \\
\hline & TANA TORAJA & 12 \\
\hline & $\begin{array}{l}\text { UJUNG } \\
\text { PANDANG }\end{array}$ & 2 \\
\hline & WAJO & 3 \\
\hline & Total & 323 \\
\hline
\end{tabular}

\begin{tabular}{|c|c|c|}
\hline PROVINSI & KAB/КOTA & $\begin{array}{l}\text { JML } \\
\text { DT }\end{array}$ \\
\hline \multirow{26}{*}{$\begin{array}{l}\text { SULAWESI } \\
\text { SELATAN }\end{array}$} & BANTAENG & 13 \\
\hline & BARRU & 7 \\
\hline & BONE & 41 \\
\hline & BULUKUMBA & 14 \\
\hline & ENREKANG & 20 \\
\hline & GOWA & 8 \\
\hline & JENEPONTO & 26 \\
\hline & LUWU & 37 \\
\hline & LUWU TIMUR & 13 \\
\hline & LUWU UTARA & 39 \\
\hline & MAJENE & 3 \\
\hline & MAMASA & 52 \\
\hline & MAMUJU & 18 \\
\hline & $\begin{array}{l}\text { MAMUJU } \\
\text { UTARA }\end{array}$ & 7 \\
\hline & MAROS & 10 \\
\hline & $\begin{array}{l}\text { PANGKAJENE } \\
\text { KEPULAUAN }\end{array}$ & 20 \\
\hline & PINRANG & 11 \\
\hline & POLMAS & 43 \\
\hline & SELAYAR & 20 \\
\hline & $\begin{array}{l}\text { SIDENRENG } \\
\text { RAPPANG }\end{array}$ & 2 \\
\hline & SINJAI & 22 \\
\hline & TAKALAR & 3 \\
\hline & TANA TORAJA & 12 \\
\hline & $\begin{array}{l}\text { UJUNG } \\
\text { PANDANG }\end{array}$ & 2 \\
\hline & WAJO & 3 \\
\hline & Total & 446 \\
\hline
\end{tabular}




\begin{tabular}{|c|c|c|}
\hline PROVINSI & KAB/KOTA & $\begin{array}{c}\text { JML } \\
\text { DT }\end{array}$ \\
\hline \multirow{10}{*}{$\begin{array}{l}\text { SULAWESI } \\
\text { TENGAH }\end{array}$} & BANGGAI & 27 \\
\hline & $\begin{array}{l}\text { BANGGAI } \\
\text { KEPULAUAN }\end{array}$ & 69 \\
\hline & BUOL & 14 \\
\hline & DONGGALA & 66 \\
\hline & MOROWALI & 70 \\
\hline & $\begin{array}{l}\text { PARIGI } \\
\text { MOUTONG }\end{array}$ & 4 \\
\hline & POSO & 6 \\
\hline & TOJO UNA-UNA & 38 \\
\hline & TOLI-TOLI & 5 \\
\hline & Total & 299 \\
\hline \multirow{11}{*}{$\begin{array}{l}\text { SULAWESI } \\
\text { TENGGARA }\end{array}$} & BAU-BAU & 1 \\
\hline & BOMBANA & 15 \\
\hline & BUTON & 55 \\
\hline & KENDARI & 91 \\
\hline & KOLAKA & 12 \\
\hline & $\begin{array}{l}\text { KOLAKA } \\
\text { UTARA }\end{array}$ & 25 \\
\hline & $\begin{array}{l}\text { KONAWE } \\
\text { SELATAN }\end{array}$ & 58 \\
\hline & $\begin{array}{l}\text { KOTA } \\
\text { KENDARI } \\
\end{array}$ & 5 \\
\hline & MUNA & 101 \\
\hline & WAKATOBI & 22 \\
\hline & Total & 385 \\
\hline
\end{tabular}

\begin{tabular}{|c|c|c|}
\hline PROVINSI & КАВ/КОТА & $\begin{array}{l}\text { JML } \\
\text { DT }\end{array}$ \\
\hline \multirow{8}{*}{$\begin{array}{l}\text { SULAWESI } \\
\text { UTARA }\end{array}$} & $\begin{array}{l}\text { BOLAANG } \\
\text { MENGONDOW }\end{array}$ & 40 \\
\hline & $\begin{array}{l}\text { KEPULAUAN } \\
\text { SANGIHE } \\
\text { TALAUD } \\
\end{array}$ & 2 \\
\hline & KOTA BITUNG & 1 \\
\hline & KOTA MANADO & 4 \\
\hline & MINAHASA & 1 \\
\hline & $\begin{array}{l}\text { MINAHASA } \\
\text { SELATAN }\end{array}$ & 20 \\
\hline & $\begin{array}{l}\text { MINAHASA } \\
\text { UTARA }\end{array}$ & 5 \\
\hline & Total & 73 \\
\hline \multirow{9}{*}{$\begin{array}{l}\text { SUMATERA } \\
\text { BARAT }\end{array}$} & AGAM & 1 \\
\hline & $\begin{array}{l}\text { KEPULAUAN } \\
\text { MENTAWAI }\end{array}$ & 35 \\
\hline & $\begin{array}{l}\text { LIMA PULUH } \\
\text { KOTO }\end{array}$ & 1 \\
\hline & PASAMAN & 1 \\
\hline & $\begin{array}{l}\text { PESISIR } \\
\text { SELATAN }\end{array}$ & 5 \\
\hline & $\begin{array}{l}\text { SAWAHLUNTO/ } \\
\text { SIJUNJUNG }\end{array}$ & 2 \\
\hline & SOLOK & 9 \\
\hline & $\begin{array}{l}\text { SOLOK } \\
\text { SELATAN }\end{array}$ & 1 \\
\hline & Total & 55 \\
\hline
\end{tabular}




\begin{tabular}{|c|c|c|}
\hline PROVINSI & КАВ/КОТА & $\begin{array}{l}\text { JML } \\
\text { DT }\end{array}$ \\
\hline \multirow{14}{*}{$\begin{array}{l}\text { SUMATERA } \\
\text { SELATAN }\end{array}$} & BANYU ASIN & 29 \\
\hline & $\begin{array}{l}\text { KOTA PAGAR } \\
\text { ALAM }\end{array}$ & 6 \\
\hline & $\begin{array}{l}\text { KOTA } \\
\text { PRABUMULIH } \\
\end{array}$ & 1 \\
\hline & LAHAT & 124 \\
\hline & MUARA ENIM & 49 \\
\hline & $\begin{array}{l}\text { MUSI BANYU } \\
\text { ASIN }\end{array}$ & 37 \\
\hline & MUSI RAWAS & 70 \\
\hline & OGAN ILIR & 53 \\
\hline & $\begin{array}{l}\text { OGAN } \\
\text { KOMERING } \\
\text { ILIR }\end{array}$ & 55 \\
\hline & $\begin{array}{l}\text { OGAN } \\
\text { KOMERING } \\
\text { ULU }\end{array}$ & 34 \\
\hline & $\begin{array}{l}\text { OGAN } \\
\text { KOMERING } \\
\text { ULU SELATAN }\end{array}$ & 62 \\
\hline & $\begin{array}{l}\text { OGAN } \\
\text { KOMERING } \\
\text { ULU TIMUR } \\
\end{array}$ & 18 \\
\hline & PRABUMULIH & 1 \\
\hline & Total & 539 \\
\hline
\end{tabular}

\begin{tabular}{|c|c|c|}
\hline PROVINSI & КАВ/КОТА & $\begin{array}{l}\text { JML } \\
\text { DT }\end{array}$ \\
\hline \multirow{19}{*}{$\begin{array}{l}\text { SUMATERA } \\
\text { UTARA }\end{array}$} & ASAHAN & 7 \\
\hline & DAIRI & 18 \\
\hline & DELI SERDANG & 14 \\
\hline & $\begin{array}{l}\text { HUMBANG } \\
\text { HASUNDUTAN }\end{array}$ & 19 \\
\hline & KARO & 14 \\
\hline & $\begin{array}{l}\text { LABUHAN } \\
\text { BATU }\end{array}$ & 10 \\
\hline & LANGKAT & 7 \\
\hline & $\begin{array}{l}\text { MANDAILING } \\
\text { NATAL } \\
\end{array}$ & 55 \\
\hline & NIAS & 186 \\
\hline & NIAS SELATAN & 151 \\
\hline & $\begin{array}{l}\text { PAKPAK } \\
\text { BHARAT }\end{array}$ & 8 \\
\hline & SAMOSIR & 51 \\
\hline & $\begin{array}{l}\text { SERDANG } \\
\text { BEDAGAI }\end{array}$ & 10 \\
\hline & SIMALUNGUN & 4 \\
\hline & $\begin{array}{l}\text { TAPANULI } \\
\text { SELATAN }\end{array}$ & 325 \\
\hline & $\begin{array}{l}\text { TAPANULI } \\
\text { TENGAH } \\
\end{array}$ & 18 \\
\hline & $\begin{array}{l}\text { TAPANULI } \\
\text { UTARA }\end{array}$ & 18 \\
\hline & TOBA SAMOSIR & 12 \\
\hline & Total & 927 \\
\hline INDONESIA & TOTAL & 10754 \\
\hline
\end{tabular}

Keterangan: di luar NAD sebesar 504 desa tertinggal 


\section{Diskusi}

Dengan melihat data di atas, perlu diperhatikan adanya peluang ketertinggalan angka-angka absolut Podes dibandingkan kondisi riil, yang terentang pada kisaran koreksi 10-50 persen. Angka yang banyak (misalnya jumlah ojek) hanya perlu koreksi persentase nan kecil, sebaliknya angka yang sedikit (contohnya jumlah KUD) mungkin menghasilkan persentase kesalahan yang lebar. Dalam kasus di Kotawaringin Timur tahun 2003 (beberapa minggu setelah pengumpulan data Podes 2003 tersebut), saya pernah mendapati pembesaran angka jumlah penduduk hingga 70 persen dari kenyataan. Barangkali hal ini terkait dengan pemekaran desa yang mensyaratkan jumlah populasi yang besar, sehingga "menggoda" aparat desa dan mantri statistik untuk memanipulasi data.

Kategorisasi menurut variabel di atas dengan segera terlihat mengandung bias desa-desa pertanian tanaman pangan dan peternakan. Masih diperlukan kriteria skoring desa-desa perikanan darat, perikanan laut, pertambangan, industri, jasa, dan "desa lain-lain". Dengan lain perkataan, reliabilitas hasil pengolahan desa tertinggal lebih tinggi pada desa-desa pertanian dibandingkan jenis desa-desa lainnya. Saya memperoleh informasi bahwa BPS telah meningkatkan jumlah variabel di atas 45 buah, sehingga tipe desa liannya tersebut terpenuhi. Namun di sini dilema di atas muncul, bahwa hasil olahannya mungkin sulit dibandingkan dengan angka desa tertinggal sebelumnya.

Selain itu, sekalipun desa di Indonesia pada tahun 2004 telah membengkak di atas 75 ribu, sensus terbaru belum dilaksanakan. Akibatnya belum terkumpul pula detil variabel ketertinggalan pada nama desa pemekaran sejak 2003. Tidak bisa lain, alternatifnya penghitungan desa tertinggal hanya memasukkan data 2003 yang berjumlah 68.816 desa di atas -yang bisa jadi menyatakan realitas desa setahun sebelumnya. Tentu saja untuk keperluan kebijakan sosial, mulamula lokasi desa lama telah dikonversi menuju nama wilayah terbaru sebagaimana tersaji pada Tabel 2 -sesuai kode desa terbaru BPS 2004 dan sumber lain. Tindakan ini mempertajam lokasi kebijakan -dalam banyak kasus sejak 2003 telah ribuan desa berpindah kecamatan, kabupaten/kota, sampai provinsi.

Namun demikian, dari desa-desa yang mekar menjadi beberapa anak desa, ternyata hanya satu desa asal yang terpaut. Artinya konversi desa terbaru masih menyisakan kekosongan kebijakan bagi dusun-dusun yang meningkat menjadi desa mandiri. Pada titik ini diperlukan langkah konsultasi pemerintah pusat dengan pemerintah daerah atau pihak lokal lainnya, sebelum pelaksanaan fisik pembangunan desa. Setelah melengkapi daftar desa tertinggal dengan ragam proyek yang masuk ke tiap desa itu, maka data ini bisa menjadi bahan awal konsultasi publik. Kontrol diperlukan, karena lazimnya pemerintah daerah mengalirkan dana dari pusat ke wilayah kerja terjauh, yang sekaligus mengalihkan pembangunan beban daerah hanya di sekitar perkotaan. Padahal ada pula kelurahan di Indonesia Timur yang ternyata tergolong tertinggal. 
Dalam konteks ini ada baiknya membedakan desa tertinggal dari desa bermayoritas penduduk miskin. Baiklah istilah "tertinggal" merujuk terutama pada tingkat kelengkapan prasarana (Friedmann, 1992), sementara "miskin" mencirikan derajat ekonomi dan kelembagaan. Dengan membanding antar Podes (tahun 1995, 1999/2000, 2003) saya menemukan garis “desa miskin" pada kisaran keberadaan 35 persen atau lebih rumahtangga miskin (tahap Pra Sejahtera/Pra KS dan Sejahtera I/KSI menurut Achir, 1994). Angka 35 persen bukannya 50 persen-sudah mengindikasikan bahwa kemiskinan menurut ukuran lokal (consensual poverty) ternyata memang lebih tinggi daripada peluang garis kemiskinan yang mungkin disusun. Temuan garis miskin di tingkat desa ini sekarang sudah digunakan antara lain dalam Program Penanggulangan Kemiskinan di Perkotaan (P2KP). Hanya saja, tampaknya untuk kepentingan politis dalam rangka pemerataan keuangan negara, tingkat kemiskinan pada garis 35 persen diturunkan menjadi 30 persen, agar kelurahan-kelurahan yang tergolong miskin meningkat, dan akhirnya pembagian dana menjadi lebih merata.

Ternyata "desa miskin" terletak di antara 51 persen desa tertinggal. Sebagai perbandingan, di tingkat nasional "desa miskin" masih melejit di angka 30 persen dari total desa. Pada tataran praktis, data ini berbicara dua peluang yang berkebalikan. Pertama, oleh karena hampir 50 persen desa tertinggal tidak didominasi penduduk miskin, maka peluang kemajuan desa lebih mudah tercapai -melalui lembaga ekonomi desa yang telah berkembang. Contohnya desa penghasil kayu atau rotan di pedalaman Kalimantan. Kedua, alokasi dana pembangunan akan mengalami tantangan dalam menjangkau penduduk miskin, sekalipun di pedesaan tertinggal.

Sebagai tambahan, menurut Podes 2003 jumlah keluarga miskin (Pra KS dan KS I) berjumlah 19.996.730 rumahtangga. Dengan asumsi sama-sama digunakan sebagai indikasi kemiskinan, maka muncul keanehan ketika dibandingkan dengan dugaan penghitungan orang miskin berbasis survai Susenas 2002. Menurut LPEM UI atau pemerintah jumlah penduduk miskin di Indonesia pada tahun 2004 kisaran 36 juta jiwa, atau menurut Komite Penanggulangan Kemiskinan pada tahun 2003 mencapai kisaran 37 juta jiwa. Pembagian jumlah penduduk miskin per rumahtangga miskin akhirnya memperoleh angka 1,8 , artinya rumahtangga miskin dihuni oleh rata-rata 1,8 jiwa. Padahal penelitian saya lainnya menunjukkan rumahtangga miskin memiliki anggota rumahtangga rata-rata 4,8 jiwa, atau menurut Podes 2003 rata-rata anggota rumahtangga di Indonesia ialah 4,5 jiwa. Ada kemungkinan garis kemiskinan berbasis Susenas perlu ditingkatkan minimal satu kali lipat, atau minimal disusun lebih tinggi lagi (White, 1996).

\section{Kesimpulan}

Secara ringkas dapat dinyatakan bahwa jumlah desa tertinggal di Indonesia saat ini mencapai 11.258 desa, atau 10.758 desa jika NAD tidak dimasukkan. Hasil 
olahan ini telah diverifikasi antar departemen dan BPS. Data ini berbasis Potensi Desa 2003 terbaru.

Kategorisasi pengolahan desa tertinggal memiliki bias pada desa pertanian, serta belum mencakup desa-desa hasil pemekaran sejak 2003. Jika desa tertinggal hendak digunakan sebagai indikasi kantong kemiskinan, perlu disadari bahwa dominasi rumahtangga miskin hanya terdapat pada 51 persen desa tertinggal.

\section{Daftar Pustaka}

Achir, YCA. 1994. "Pembangunan Keluarga Sejahtera sebagai Wahana Pembangunan Bangsa" (Welfare Family Development as a Nation Development Instrument), in Prisma Vol. 13 No. 6, Mei.

Supriatna, T. 1997. Birokrasi, Pemberdayaan dan Pengentasan Kemiskinan. Humaniora Utama Press. Bandung.

Friedmann, J. 1992. Empowerment: The Politics of Alternative Development. Blackwell. Cambridge, Mass.

White, B. 1996. "Optimisme Makro Pesimisme Mikro? Penaksiran Kemiskinan dan Ketimpangan di Indonesia, 1967-1987”, dalam MTF Sitorus, et.al. Memahami dan Menanggulangi Kemiskinan di Indonesia: Prof. Dr. Sajogyo 70 Tahun. Gramedia. Jakarta. 
252 | Agusta, I. Desa Tertinggal Indonesia 